\title{
Research on Teaching Reform of Basic Computer Course in College
}

\author{
Jianyan Zhang*, Junshe Wang, Xiaoming Zhang \\ School of Information Science and Engineering \\ Hebei University of Science and Technology \\ Shijiazhuang, China \\ zjy@hebust.edu.cn, wangjunshe@hebust.edu.cn, zhangxiaom@ hebust.edu.cn \\ * Corresponding Author
}

\begin{abstract}
With the rapid development of information technology as well as the popularization of computer and network, in order to meet the different needs of the students' basic knowledge of computer, bring into full play the initiative of students for learning basic computer knowledge, and strengthen the students' practical ability, how to reform the teaching method of basic computer courses in college is becoming an important subject of undergraduate education in universities. This paper analyses current situation and existing problems of basic computer courses teaching in universities, explores a teaching model based on subject classification and target stratification, and then introduces the "computational thinking" ability training and the project-based teaching method into the teaching process of courses. Through 3 years of teaching practice, a significant teaching effect has been achieved on promoting the students' problem-solving ability and innovation ability.
\end{abstract}

Keywords-basic computer courses in college; subject classification; target stratification; computational thinking; project-based

\section{INTRODUCTION}

With the rapid development of computer technology and the popularization of computers, the computer application has permeated into every aspect of industries and lives, which makes mastering the basic operation of computer and using universal software literacy the basic quality modern college students should have. Basic computer courses teaching in college is a compulsory course for every student, and traditional practice teaching methods are a certain lack of practicality and innovation because of the limitations of human, material and other factors at practice, which leads to the students' lack of problem solving and analytical skills. Therefore, how to reform the teaching method of basic computer courses in university so as to train and improve computing practice ability has become an important research challenge.

\section{THE CURRENT TEACHING SITUATION}

\section{A. Outmoded Teaching Content}

The updating speed of computers becomes faster and faster, so the current teaching contents falls behind the development speed of computers, which greatly hinders students' intrinsic motivation and initiative to learn basic computer courses teaching in college. They study for the final exam instead of improving computing application ability. Teachers can't play a better role in cultivating students' computer application consciousness, and students don't know how to use a computer effectively.

\section{B. Shortage of The Course Knowledge}

Many college students have negative attitudes toward basic computer courses teaching in college, and neglect the important role in cultivating their abilities. There exist some unilateral standpoints: some equate computer course with program design, and others argue that the course shows how to use computer and acquiring the ability of operating computer is enough ${ }^{[1]}$. Most of the students in college fail to recognize that computer science is one of the basic ideas and important methods which can be used by students to analyze and solve professional problems, so they cannot comprehend the course as a whole and capture the metaphor of basic computer courses teaching in college.

\section{Unbalanced Computer Level}

For the freshmen in class, there exists dissimilarity on their computer levels, which is mainly caused by different economic strength, education levels and regional differences. Teachers find it hard to behave accurately in the teaching process.

\section{THE REFORM CONTENTS AND MEASURES}

\section{A. Establishing New Teaching Pattern}

A teaching mode of basic computer courses teaching in college based on subject classification and target stratification was introduced in 2013.

Depending on different major's characteristics and requirements, the subject classification divides basic computer courses teaching in college into three kinds: the course in art and gym, the course in literature and management and the course in science. According to the basic teaching documents formulated by Steering Committee of the Ministry of education, National College Computing Basic Teaching and different major's characteristics, we develop a new curriculum of basic computer courses teaching in college. Teachers can select teaching materials, which adapt different course's teaching requirement and aim.

The target stratification is that the entire freshmen will be tested for basic computer skills and the test results can 
be classified into three grades: A, B, C in terms of their mastery of computer.

$\mathrm{C}$ refers to the basic teaching requirement grade. The corresponding teaching content can be actualized according to the basic curriculum, and the students should master the basic computer theories, ideas and skills.

$\mathrm{B}$ refers to the higher teaching requirement grade. After the students master the basic teaching contents, some basic computer knowledge can be further extended so as to train students' ability of comprehension and application.

A refers to the highest teaching requirement grade. After the students master the basic teaching contents, the teaching mode aims to enhance students' professional skills and innovation in the form of increasing minors, organizing all kinds of classes or coaching students for various events.

\section{B. System of Classification on Curriculum}

The students' ability in computer application falls into three directions, which includes operating skills, application development capabilities, and research and innovation capabilities ${ }^{[2]}$. The system divides basic computer courses teaching in college into three kinds: the course in art and gym, the course in literature and management, and the course in science. The first step is to make sure the public foundation module by student ability raise request, and the second step is to make the core module and the extension module by different major's characteristics, which are affiliated with a grade. The system structure of classification on basic computer courses teaching in college is shown in TABLE I.

The system further determines teaching contents of various modules, and develops relevant teaching curriculums and educational requirements in three grades. From TABLE I, the system structure of classification on basic computer courses teaching in college meets the development of science and technology and social needs, and can reflect professional features and innovation. The teaching contents broaden students' perspectives, and are helpful to develop the creative ability of the students while maintaining basic knowledge and basic concepts.

\section{Reform of Teaching Method}

1) Taking Computational Thinking as the Core. Computational thinking is a series of thinking activities over the field of computer science, which is applied to solve problems, design systems and understand human behaviors by using basic concepts of computer science. The nature of computational thinking is abstraction and automation ${ }^{[3-6]}$. While teaching, one of the goals is to teach the ability to use computational thinking to think and solve problems and gradually undergo the transition from basic operation ability exercise to the cultivation of computational thinking ability. Hebei University of Science and Technology began to develop pilot programs, and offered a course called The Computational Thinking and Algorithmic Design for students, which would lay the foundation for developing the students' ability to use computational thinking to analyze problems and design programs, starting in 2014.

2) Introducing the Project-based Teaching Method. As for the project-based teaching method, teachers create good teaching situation in class according to the project designed by teachers, and students grasp teaching content and achieve teaching target by finishing special projects by way of collaborative learning ${ }^{[7-9]}$. The most distinguishing feature of the project-based teaching method is that it takes the projects as the thread, the teachers as leadership, and the students as main body. Students will be inspired to learn positively and think actively, which can ensure a good teaching effect. The project-based teaching method is used in Programming course ${ }^{[10]}$. The entire flow is shown in Fig. 1

TABLE I. SYSTEM STRUCTURE OF CLASSIFICATION ON BASIC COMPUTER COURSES TEACHING IN COLLEGE

\begin{tabular}{|c|c|c|c|}
\hline Krofessional Category & $\begin{array}{c}\text { Course in Art and } \\
\text { Gym }\end{array}$ & Course in Literature & Course in Science \\
\hline \multirow{3}{*}{ Public Module } & \multicolumn{3}{|c|}{ Overview of Computer Knowledge } \\
\hline & \multicolumn{3}{|c|}{ Representing Information of Computer } \\
\hline & \multicolumn{3}{|c|}{ Structures and Principles of Computer System } \\
\hline \multirow{5}{*}{ Core Module } & Windows & Computer Operation System and Application & Operation System \\
\hline & Word & Office Automation & Computer Network \\
\hline & Excel & Multimedia Knowledge and Application & Database Application \\
\hline & PowerPoint & Network Basic & Software Development \\
\hline & Internet & Internet Application & \\
\hline \multirow{2}{*}{ Extension Module } & Photoshop & Information Retrieval and Processing & Information Security \\
\hline & Access & Web Design & $\begin{array}{l}\text { Multimedia Technology and } \\
\text { Application }\end{array}$ \\
\hline
\end{tabular}




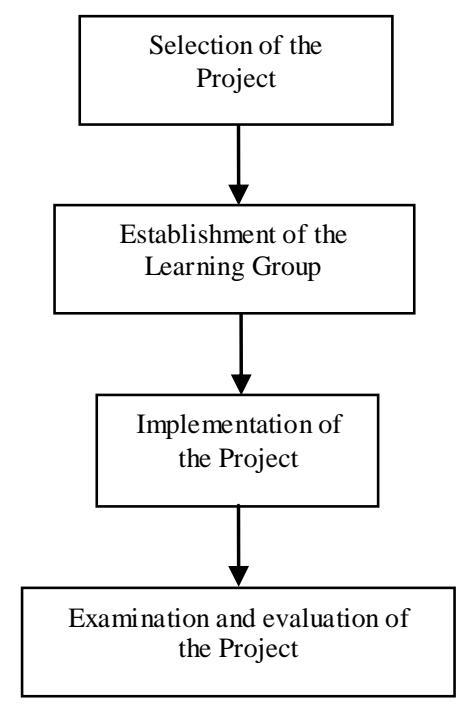

Figure 1. The entire flow of the project-based teaching method

The project-based teaching method steps include mainly the following four aspects.

a) Selection of the project. The teacher designs the course project according to full understanding of the specialty nature, the teaching goal and students' actual situation, and designs the unit project according to the content of relevant units. It is necessary to show some excellent works, in order to make each student have enough definitude with task.

b) Establishment of the learning group. Students will be divided into several groups of about 7 people based on the level of difficuty of the project and student performance, and every group elects a leader who is responsible for distributing the assignments, the supervision over the preparation, execution of the project, etc.

c) Implementation of the project. The students complete a group project through self-study and cooperation, and it trains the students to find, analyze and solve problems more systematically and scientifically, so as to cultivate the students to think independently. Teachers' main task is to make necessary guidance.

d) Eamination and evaluation of the project. The project schedule is measured by the teaching plan, and teachers should praise excellent group, and explain in detail common problems and errors in the project. According to teachers' evaluation, group evaluation and self-evaluation, the final analysis and appraisal to the project results are given, and students will find fulfillments and gain selfconfidence in this process.

\section{Digital Resources Constructions}

The teaching pattern builds up thee-study center, increases rich digital curriculum resources, and provides students with the convenience of initiative study. The network platform provides teaching materials which are in pace with classroom teaching, such as the syllabus, the electronic teaching plan, the video cases, the experimental guidance, the operation practices on machine and so on, and also provides interactive functions for teachers and students, such as BBS, the personal space and so on. Teachers can update and extend teaching contents according to the students' feedback information in a timely manner on this network platform. This way will raise the ability of computer comprehensive practice for students. Hebei University of Science and Technology began to carry out MOOC/SPOC teaching and Flipped Classroom, starting from 2015.

\section{E. Selection of the Textbook}

The system develops different teaching syllabuses and selects relevant textbooks based on the basic teaching requirement, teaching contents and knowledge of the subject classification. The same subject different grades use the same textbook, the proportion in class hour arranger and teaching contexts are different. Besides, teachers specify reference 3-5 books for students whose grade is A or B as supplementary materials.

\section{F. Assessment Method of Courses}

The final score of a course is made up of two parts, i.e., usual score and final exam result. The final exam will be in the form of computer test which assesses the degree of students' mastery of the course content mainly through setting objective questions and operation ones. We design the question pool according to the level of students from different subject categories. Then examination questions can be selected from the question pool mentioned above randomly. Once examinations are done, the system will give corresponding results automatically. This assessment method not only exercises students' ability to operate the computer, but also avoids teachers' complicated marking work. At the same time, it ensures the accuracy of assessment, which results in the improvement of teaching quality.

\section{CONCLUSION}

In the information age, college computer teaching must face up to its own problems and conduct teaching reform and innovation which based on the target improving students' knowledge of theory and operation skills. New reforms aim to train students' independent thinking ability and creative thinking ability, promote the learning interest of students by importing the new technologies of computer to the teaching process, and foster interdisciplinary talents to meet the need of the society.

\section{ACKNOWLEDGMENT}

This work is supported by the Higher Education Teaching Reform Project in Hebei Province (Training system of practical ability for information talents), and the Reform Pilot Project of Innovative Talents Training Mode of Hebei University of Science and Technology.

\section{REFERENCES}

[1] X. Zhang, F. Chen, R. Li, and G. Li. "Teaching reform of university computer foundation courses under 'One Body, Two Wings' talent training mode" $[\mathrm{J}]$, Experrimental Technology and Management, 2013,30(11):199-202

[2] X. Li. "Study of computer application ability training of college students"[J]. Intellicent Computer and Applications. 2014, 4(6):9092.

[3] J. M. Wing. "Computational thinking" [J]. Communications of the ACM, 2006. 49(3):33-35.

[4] J. M. Wing. "Computational Thinking and Thinking about Computing" [J]. Philosophical Transactions of the Royal Society, 2008, 366:3717-3725 
[5] Z. Wang. Introduction to Computational Thinking. Beijing: Higher Education Press, 2012.

[6] F. Guo, L. Cui, Y. Li, G. Zhou. "Exploration on the teching reform of computer basic courses based on computational thinking capabilities training" [J]. Computer Engineering \& Science, 2014, 36 (A2): $162-164$.

[7] L. Zhang. "Basic teaching of computer and the evaluation based on the projedt based learning" [J]. Journal of Southwest China Normal University (Natural Science Edition), 2012,37(6):245-248.
[8] B. Liu, Y. Shen, Y. Zeng. "Research on the driving teaching pattern by computer projects in colleges" [J]. Computer Education, 2011, (4):82-84

[9] C. Wang. "Exploration and practice of project experience type teaching in information technology courses" [J]. Journal of Shanxi Finance and Economics University, 2013,35(S3):65-70.

[10] X. Zhang, Q. Chen, S. Duan, B. Hu. "Study and application of project teaching method in the 'C language courses design' " [J]. Experrimental Technology and Management, 2011, 2(28): 164-167 